CLINICAL STUDY

\title{
Metabolic and hormonal changes during the refeeding period of prolonged fasting
}

\author{
Márta Korbonits $^{1}$, David Blaine ${ }^{3}$, Marinos Elia ${ }^{3}$ and Jeremy Powell-Tuck ${ }^{2}$ \\ ${ }^{1}$ Department of Endocrinology and ${ }^{2}$ Centre for Adult and Paediatric Gastroenterology, Barts and the London Medical School, London EC1A 7 BE, UK and \\ ${ }^{3}$ Institute of Human Nutrition, University of Southampton, Southampton SO16 6YD, UK
}

(Correspondence should be addressed to M Korbonits who is now at Department of Endocrinology, Barts and the London Medical School, John Vane Science Centre, Charterhouse Square, Room 114C, London EC1M 6BQ, UK; Email: m.korbonits@qmul.ac.uk)

\begin{abstract}
Objective: The discovery of leptin, a hormone primarily involved in adaptation to fasting, led to an increased interest in appetite regulation and appetite-modulating hormones. Here, we present unique data from a case of extreme starvation and refeeding, showing changes in plasma concentrations of appetite-modulating and metabolic hormones as well as biochemical changes, and draw attention to the dangers of the refeeding syndrome.

Patients and methods: We studied the refeeding period of a 44-day voluntary fast uncomplicated by underlying disease. Biochemical and hormonal variables were compared with 16 matched subjects such that the BMI range of the controls covered the entire spectrum for the index subject's recovering BMI.

Results: Lack of calorie intake with free access to water resulted in 25\% loss of body weight. Haemoconcentration was observed and feeding was started with a low sodium, hypocaloric liquid formulation. During early refeeding, marked hypophosphataemia, haemodilution and slight oedema developed. Vitamins B1, B12 and B6 were depleted while serum free fatty acids, ketone bodies and zinc levels were abnormally high; abnormal liver function developed over the first week. The hormonal profile showed low IGF-I and insulin levels, and elevated IGF-binding protein-1 concentrations. Appetite-regulating hormones were either very low (leptin and ghrelin) or showed no marked difference from the control group (peptide YY, agouti-related peptide, $\alpha$-melanocytestimulating hormone, neuropeptide $\mathrm{Y}$ and pro-opiomelanocortin). Appetite was low at the beginning of refeeding and a transient increase in orexin and resistin was observed coincidently with an increase in subjective hunger.

Conclusions: Our study illustrates the potential dangers of refeeding and provides a comprehensive insight into the endocrinology of prolonged fasting and the refeeding process.
\end{abstract}

European Journal of Endocrinology 157 157-166

\section{Introduction}

Starvation and obesity cause characteristic changes in appetite hormones, such as low leptin levels in starvation and high leptin and low ghrelin levels in obesity. Starvation can lead to death but the exact cause of this is often unclear. While in famine situations, a BMI of $10 \mathrm{~kg} / \mathrm{m}^{2}$ can be compatible with life (1), hunger strikers die before such emaciation occurs, suggesting a wide variation in the tolerance of starvation. The early stages of starvation's treatment also put the vulnerable patient at the risk of death in a way that is analogous to the dangers of fatal water and electrolyte imbalance during the treatment of diabetic ketoacidosis, and this is further compounded by vitamin B deficiency. Indeed, the management of starvation and diabetic ketoacidosis has one striking similarity - the sudden shift of a low insulin, fat-burning metabolism to a high insulin, glucose-based state. The potentially fatal clinical syndrome associated with the treatment of malnutrition has been called the refeeding syndrome. Its importance lies not only in the relief of famine but also in the management of the disease-related malnutrition prevalent in our hospitals.

Concepts of the refeeding syndrome have evolved since the 1940s when the dangers of oedema, acute heart failure and the precipitation of acute vitamin B1 deficiency during the relief of war-related famine were already recognized $(8,9)$. The relationships between insulin secretion and sodium retention were characterized during the 1960s (10). Hypophosphataemia had previously been recognized as a complication of glucose infusions and the treatment of diabetic ketoacidosis, but its association with refeeding was established as parenteral feeding was popularized (11). Also during the early 1970s, red cell hypophosphataemia was 
shown to result in the accumulation of triose phosphates, but decreased 2,3-diphosphoglycerate, depressed ATP and abnormal oxygen dissociation, causing hypoxia in the central nervous system (12). Opportunities to study the effects of prolonged fasting and subsequent refeeding in an otherwise normal individual are rare - it is not usually possible in hunger strikers. Our case study demonstrates the management of food reintroduction and adds new information on the hormonal and peptide responses to refeeding. Following a short case description (2), in this paper a full description of the clinical, biochemical and endocrinological findings and processes is provided.

\section{Subjects and methods}

A 30-year-old male, weight $96 \mathrm{~kg}$, height $1.84 \mathrm{~m}$, entered a transparent Perspex box on the banks of the river Thames in London and was suspended in the air from a crane for 44 days. During this period, he took only water to drink. Following the fast, he was transferred by ambulance, in which he took nothing by mouth, to hospital under the care of J P-T, where after initial blood sampling, he underwent controlled refeeding. The early refeeding was done orally, using Ensure Plus (Abbot Laboratories), a standard nutritionally complete liquid formulation, containing $330 \mathrm{kcal}$, $44.4 \mathrm{~g}$ carbohydrate of which $12.7 \mathrm{~g}$ sugars, $10.8 \mathrm{~g}$ fat, $13.8 \mathrm{~g}$ protein, $11.5 \mathrm{mmol}$ sodium, $11.3 \mathrm{mmol}$ potassium, $6.4 \mathrm{mmol}$ calcium, $6.5 \mathrm{mmol}$ phosphate and $2.7 \mathrm{mmol}$ magnesium per carton $(220 \mathrm{ml})$ using the following regimen:

Day 0 overnight 2 cartons Ensure Plus and water ad libitum

Day $1 \quad 2$ cartons Ensure Plus and water ad libitum

Day 25 cartons Ensure Plus and water ad libitum

Day 36 cartons Ensure Plus and water ad libitum

Day $4 \quad 1500 \mathrm{kcal}$ approximately as a light diet

Day 5 ad libitum, though he was encouraged to be cautious

In addition, the following supplements were given from the time of his admission: $50 \mathrm{mg}$ thiamine twice a day, $80 \mathrm{mg}$ niacin, $8 \mathrm{mg}$ vitamin $\mathrm{B} 6,8 \mathrm{mg}$ vitamin $\mathrm{B} 2$ and $20 \mathrm{mg}$ vitamin B1 (4 tablets of vitamin B compound strong, British National Formula) daily, $5 \mathrm{mg}$ folic acid daily, Forceval capsules (Unigreg, Morden, UK) containing vitamins and trace elements, 1 capsule twice a day, $24 \mathrm{mmol}$ effervescent $\mathrm{KCl}$ three times a day for 2 days and then $12 \mathrm{mmol}$ three times daily.

By the evening of day 1 , he became hypophosphataemic (serum phosphate $0.46 \mathrm{mmol} / \mathrm{l}$, normal range $1.2-1.7 \mathrm{mmol} / \mathrm{l}$ ) and, in addition, he was therefore given $250 \mathrm{ml}(25 \mathrm{mmol})$ Polyfusor phosphate intravenously over $12 \mathrm{~h}$ and effervescent phosphate (16 mmol) twice daily orally on days $2-4$. The i.v. phosphate was the only i.v. fluid or feed he received. He left hospital on day 5 with advice not to overeat.

With written consent, blood was taken on arrival in hospital at $2215 \mathrm{~h}$ on 19 October 2003 (day 0) and, after overnight fasts, on days 3, 5, 10 and 46 of the refeeding period. As an approximation of his basal state, a blood sample was also taken after full recovery, 236 days after starting refeeding. These samples were used for biochemistry and hormone assessments. During the early refeeding period, further blood samples were taken for appropriate clinical management. Routine biochemical parameters (full blood count, urea, electrolytes, plasma glucose, aspartate aminotransferase (AST), alanine aminotransferase (ALT), serum bilirubin, albumin, serum calcium, serum phosphate and cholesterol), free thyroxin $\left(\mathrm{fT}_{4}\right)$, total tri-iodothyronine $\left(\mathrm{tT}_{3}\right)$, thyroidstimulating hormone (TSH), luteinizing hormone (LH), follicle-stimulating hormone (FSH), testosterone, oestradiol, sex hormone-binding globulin (SHBG), dehydroepiandrosterone sulphate (DHEAS), androstenedione (A4), prolactin, insulin, cortisol, growth hormone and insulinlike growth factor I (IGF-I) were measured in the routine clinical laboratory (Barts \& London Hospital and the London Independent Hospital). Free fatty acids (FFA), 3-hydroxybutyrate, homocysteine and amino acids were measured in the clinical laboratory of Great Ormond Street Hospital, while vitamins and trace elements were measured in the laboratories of Institute of Human Nutrition and Southampton University Hospitals Trust. Other hormones were measured by commercial or research immunoassays: total ghrelin, leptin, resistin and adiponectin (Linco, St Charles, Missouri USA); agoutirelated peptide (AgRP), pro-opiomelanocortin (POMC) and orexin A (IDS, Newcastle, UK), $\alpha$-melanocytestimulating hormone $(\alpha-\mathrm{MSH})$ and neuropeptide $\mathrm{Y}$ (NPY; Euro-Diagnostica, Malmo, Sweden) and glucagon, somatostatin, pancreatic polypeptide (PP) and peptide YY (PYY) (3) (Hammersmith Hospital, Imperial College, UK). Samples were collected into serum, EDTA and lithiumheparin tubes with or without trasylol, spun immediately, and frozen at $-70{ }^{\circ} \mathrm{C}$ until analysis. Analyses for the controls and the index subject for given metabolites, peptides or hormones were conducted together in the same run in duplicates, and intra-assay coefficients of variation were $<10 \%$.

The changes in body composition were calculated from skinfold thicknesses using established equations of Durnin and Womersley (4), appropriate for age and gender. Mid-upper arm circumference and four skinfold thicknesses (biceps, triceps, subscapular and suprailiac skinfold thicknesses) were measured before the fast and during refeeding. Although there are more precise methods to assess body composition, care was taken to use the same observer and the same instrument and a 
mean of three measurements each time to keep variability low. The subject kept a personal diary during the refeeding period.

\section{Control subjects}

Blood samples were taken after an overnight fast $(13.3 \pm 2.1 \mathrm{~h}$ s.D.) from 16 age-matched male controls whose BMIs spanned the range of the BMI of the index subject seen over the whole refeeding period $\left(20-29 \mathrm{~kg} / \mathrm{m}^{2}\right)$.

\section{Ethics}

The voluntary fast described here was designed by D B and his colleagues independently of the other authors. $\mathrm{M}$ E was involved in monitoring D B during his period of starvation. J P-T treated him after his admission to hospital at the end of the starvation. Local Research Ethics Committee permission was granted, and written informed consent was obtained from the fasting subject on arrival in hospital, for taking anthropometric measurements and collecting blood samples during the refeeding period. Written informed consent was taken from all the control participants and the study was approved by the local ethics committee.

\section{Statistical analysis}

Data are expressed as mean and range of the control subjects or mean and 95\% confidence interval.

\section{Results}

The index subject lost $25 \%$ of his weight, $24 \%$ of his fatfree body mass and 33\% of his fat mass as judged by anthropometric measurements (Table 1). Detailed analyses of macro- and micronutrient losses during the fast are provided in a separate paper (5).

His metabolic status on arrival in hospital showed a normal plasma glucose, normal cholesterol and triacylglycerol, but considerably elevated FFA and much elevated 3-hydroxybutyrate (Fig. 1, Table 2). A raised haematocrit on admission (reflecting haemoconcentration) changed to progressively lower values, despite cautious refeeding, and total avoidance of saline or additional salt during the hospital stay (Table 3). Albumin concentration on admission to hospital was slightly raised and declined gradually over 5 days probably due to plasma expansion. By day 10, 5 days after he left hospital on a free diet, he demonstrated mild pitting oedema. Blood pressure and pulse on arrival in hospital were $109 / 74 \mathrm{mmHg}$ and $89 / \mathrm{min}$ supine, and 109/65 $\mathrm{mmHg}$ and $119 / \mathrm{min}$ standing. The electrocardiogram was normal with a $\mathrm{QT}_{\mathrm{c}}$ interval of $405 \mathrm{~ms}$.

Hypophosphataemia developed through day 1 and blood phosphate concentrations dropped below $0.5 \mathrm{mmol} / \mathrm{l}$. This required overnight i.v. intervention as mentioned earlier (6). While serum transaminases (AST and ALT) were normal at the end of the fast, elevated concentrations were detected by day 10 (Table 3). They subsequently returned to normal. Serum zinc was elevated on admission but rapidly returned to normal during refeeding. Serum copper and selenium were within the normal ranges after the fast. Our functional assays indicated vitamins B1, B2 and B6 deficiencies at day 0 of refeeding (Fig. 1). These were corrected to normal by day 3 in the case of vitamins B1 and B2 and by day 5 in the case of vitamin B6. Vitamin B12 was abnormally elevated $(>1500 \mathrm{ng} / \mathrm{l})$ and fell gradually with refeeding, although it was still $555 \mathrm{ng} / \mathrm{l}$ at day 236 (range of controls 194-419 ng/l; Fig. 1). Serum folate was just above the lower limit of the normal range and was raised by the treatment he received. There was no abnormality in homocysteine levels. Essential amino acid serum concentrations showed lower values than the minimum of the control subjects for asparagine, histidine, threonine, arginine, tryptophan and lysine on day 0 , while branched chain amino acid concentrations were elevated as is typical of a low insulin state (7) (data not shown). All amino acids normalized by day 46 .

Hormone results are shown in Figs 2 and 3 and Table 4 . Cortisol on admission was high at $777 \mathrm{nmol} / \mathrm{l}$. IGF-I concentrations were very low compared with ageand sex-matched controls (Fig. 2) and gradually

Table 1 Body weight, fat-free mass and basal metabolic rate during the refeeding period.

\begin{tabular}{|c|c|c|c|c|c|c|c|}
\hline & Start of fast & Day 0 & Day 3 & Day 5 & Day 10 & Day 46 & Day 236 \\
\hline Weight (kg) & 96.0 & 71.5 & 71.5 & 72.2 & 80.9 & 89.9 & 91.6 \\
\hline BMI $\left(\mathrm{kg} / \mathrm{m}^{2}\right)$ & 28.3 & 21.1 & 21.1 & 21.3 & 23.9 & 26.6 & 27.1 \\
\hline Percentage of fat & 20.1 & 18.1 & & & & 20.9 & 21.9 \\
\hline Fat mass $(\mathrm{kg})$ & 19.2 & 12.9 & & & & 18.8 & 20.1 \\
\hline $\mathrm{FFM}^{\mathrm{a}}(\mathrm{kg})$ & 76.7 & 58.6 & & & & 71.2 & 71.5 \\
\hline $\mathrm{BMR}^{\mathrm{b}}$ (kcal) & 2047 (e) & $1723(e)$ & & $1775.5(\mathrm{~m})$ & & $2322.6(\mathrm{~m})$ & 1989 (e) \\
\hline
\end{tabular}

${ }^{\text {a }}$ Fat-free mass (FFM) is calculated from four skinfold measurements using the equations of Durnin and Womersley (4).

${ }^{b}$ Basal metabolic rate (BMR) is given (e) estimated based on the calculated mean of the results of the two Schofield equations applicable to a 30 -year-old male and $(\mathrm{m})$ measured by indirect calorimetry (Deltatrac, GE Healthcare, UK). 

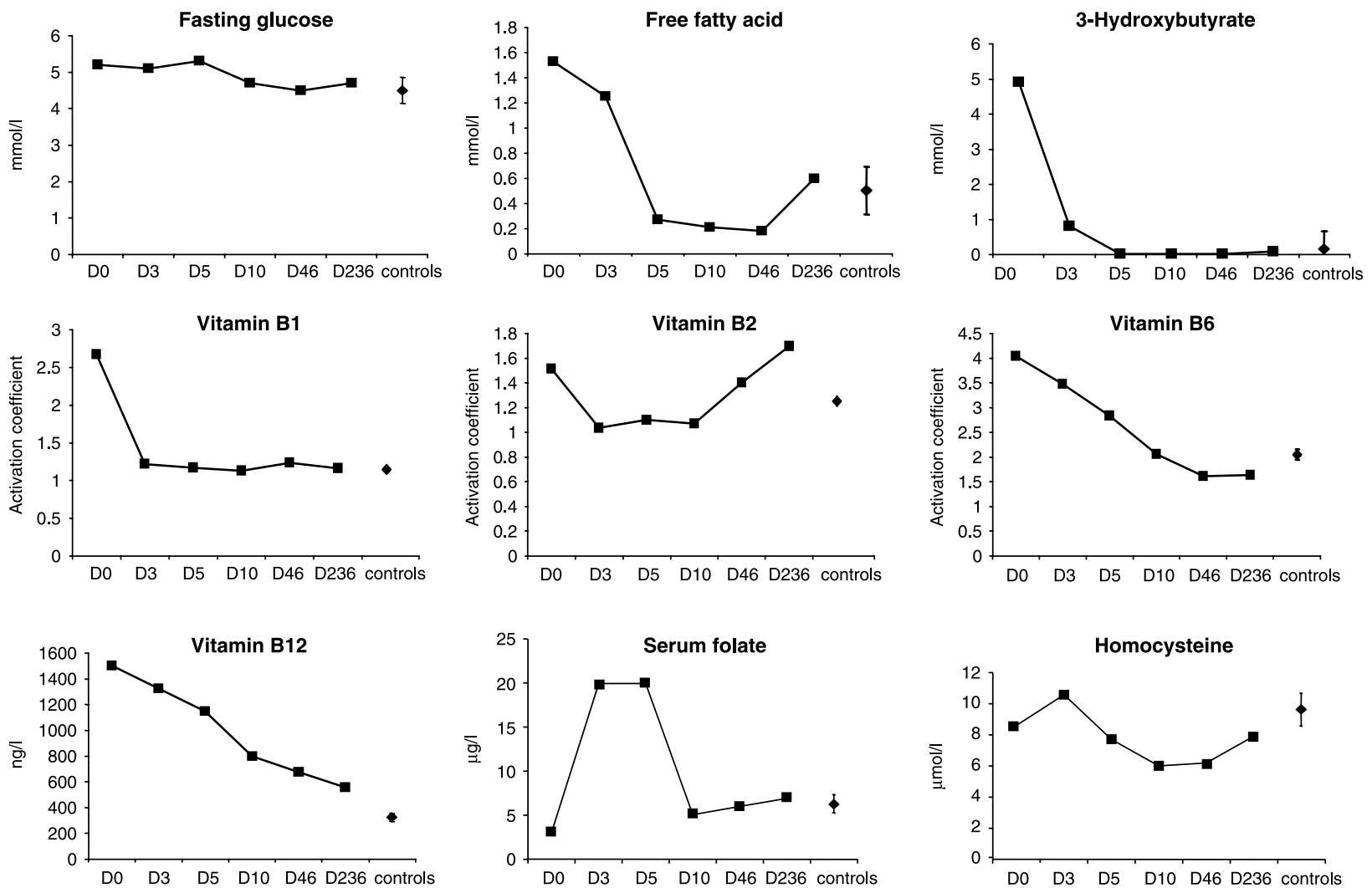

Figure 1 Free fatty acids and 3-hydroxybutyrate concentrations were high on day 0 , while plasma glucose was well preserved. Vitamin $B$ measurements showing vitamins B1, B2 and B6 deficiency and very high B12 levels. Vitamin B1, erythrocyte transketolase activation coefficient (ETKAC), vitamin B2, erythrocyte glutathione reductase activation coefficient (EGRAC), vitamin B6, erythrocyte aspartate aminotransferase activation coefficient (EAATAC): elevated results in these assays suggest vitamin deficiency. Data for volunteers are shown as mean $\pm 95 \%$ confidence interval.

returned to normal. High IGF-binding protein 1 (IGF-BP1) concentrations were recorded (Fig. 2), while IGF-BP 3 followed the pattern of IGF-I. Growth hormone values were variable and remained in the normal range. TSH concentrations were slightly above the normal range on day $0(6.1 \mathrm{mU} / \mathrm{l}$; Fig. 2) and returned to normal within 3 days, while $\mathrm{fT}_{4}$ and $\mathrm{tT}_{3}$ levels were normal. In the first 10 days of the refeeding period, increasing concentrations of $\mathrm{FSH}$ (from 1.2 to $4.7 \mathrm{mU} / \mathrm{l}$ ), testosterone (from 15.6 to $30.1 \mathrm{nmol} / \mathrm{l}$ ) and oestradiol (from 70.8 to $204 \mathrm{pmol} / \mathrm{l}$ ) and decreasing concentrations of SHBG (from 81 to $32 \mathrm{nmol} / \mathrm{l}$ ) and DHEAS (from 11.6 to $4.3 \mu \mathrm{mol} / \mathrm{l}$ ) were observed. Several prolactin levels were at the upper end of the normal range, possibly due to stress. $\mathrm{LH}$ and A4 concentrations were within the normal range.

Very low leptin concentrations were observed on day 0 (under the lower limit of our assay at $1.7 \mu \mathrm{g} / \mathrm{l}$ ) which gradually normalized (to $6.5 \mu \mathrm{g} / \mathrm{l}$ ). Adiponectin concentrations were three times higher on day $10(71.9 \mu \mathrm{g} / \mathrm{l})$ than on the previous or following days. High somatostatin concentrations were observed on day 0 which gradually dropped during refeeding (from 45.9 to $25.2 \mathrm{pmol} / \mathrm{l})$. The concentrations of other anorectic peptides (PYY, PP, glucagon, $\alpha$-MSH and POMC) showed no marked changes within the first 10 days of refeeding. Orexigenic peptide ghrelin concentrations on day 0 were very low (total ghrelin $27.6 \mathrm{pmol} / \mathrm{l}$ ) and returned to normal values within 5 days $(100.1 \mathrm{pmol} / \mathrm{l})$. Plasma resistin and orexin A showed an elevation on day 3 with $3 \times$ higher concentration for resistin and $10 \times$ higher for orexin A compared with the previous and following days. The concentrations of orexigenic peptides NPY and AgRP showed no marked changes within the first 10 days of refeeding. There was no correlation between

Table 2 Selected biochemical parameters on day 0.

\begin{tabular}{lcc}
\hline & Day 0 & Normal range \\
\hline Cholesterol & 5 & $3.5-6.2 \mathrm{mmol} / \mathrm{l}$ \\
Triacylglycerol & 0.95 & $0.6-2.83 \mathrm{mmol} / \mathrm{I}$ \\
Serum folate & 3.1 & $2.9-18.0 \mathrm{nmol} / \mathrm{l}$ \\
Vitamin A & 0.9 & $1.0-2.8 \mathrm{mmol} / \mathrm{l}$ \\
Vitamin E & 21 & $15-40 \mathrm{mmol} / \mathrm{l}$ \\
Zinc & 31.7 & $11-24 \mathrm{mmol} / \mathrm{l}$ \\
Copper & 15.2 & $12-26 \mathrm{mmol} / \mathrm{l}$ \\
Selenium & 1.52 & $0.8-2.0 \mathrm{mmol} / /$ \\
\hline
\end{tabular}


Table 3 Biochemical parameters during refeeding.

\begin{tabular}{lcccccccc}
\hline & Day 0 & Day 1 & Day 2 & Day 3 & Day 5 & Day 10 & Day 46 & Normal range \\
\hline Hct & 0.47 & 0.46 & 0.46 & 0.44 & 0.39 & 0.39 & - & $0.40-0.54 \mathrm{l} / \mathrm{l}$ \\
Urea & 0.7 & 1.7 & 1.8 & 2.2 & 3.3 & 3.3 & 4.0 & $3.2-7.1 \mathrm{mmol} / \mathrm{l}$ \\
$\mathrm{K}$ & 3.3 & 4.0 & 4.0 & 3.7 & 3.8 & 4.3 & 4.1 & $3.6-5.0 \mathrm{mmol} / \mathrm{l}$ \\
$\mathrm{Na}$ & 140 & 141 & 142 & 141 & 142 & 144 & 146 & $137-145 \mathrm{mmol} / \mathrm{l}$ \\
$\mathrm{PO}_{4}$ & 1.0 & 0.46 & 1.46 & 1.36 & 1.26 & 1.22 & 1.19 & $1.2-1.7 \mathrm{mmol} / \mathrm{l}$ \\
Albumin & 52.9 & 44.0 & 42.6 & 44.6 & 33.0 & 34.2 & 41.2 & $39-50 \mathrm{~g} / \mathrm{l}$ \\
Total bilirubin & 15 & 15 & 22 & 17 & 6 & 5 & 13 & $3-22 \mu \mathrm{mol} / \mathrm{l}$ \\
$\mathrm{ALP}$ & 66 & 70 & 57 & 72 & 74 & 67 & 76 & $38-126 \mathrm{U} / \mathrm{l}$ \\
$\mathrm{ALT}$ & 62 & 57 & 73 & 73 & 65 & 218 & 184 & $21-72 \mathrm{U} / \mathrm{l}$ \\
$\mathrm{AST}$ & 44 & 38 & 62 & 55 & 51 & 157 & 51 & $14-50 \mathrm{U} / \mathrm{l}$ \\
GGT & 21 & 19 & 18 & 22 & 18 & 23 & 29 & $8-78 \mathrm{U} / \mathrm{l}$
\end{tabular}

Hct, haematocrit; ALP, alkaline phosphatase; AST, aspartate aminotransferase; ALT, alanine aminotransferase; GGT, $\gamma$-glutamic transpeptidase.
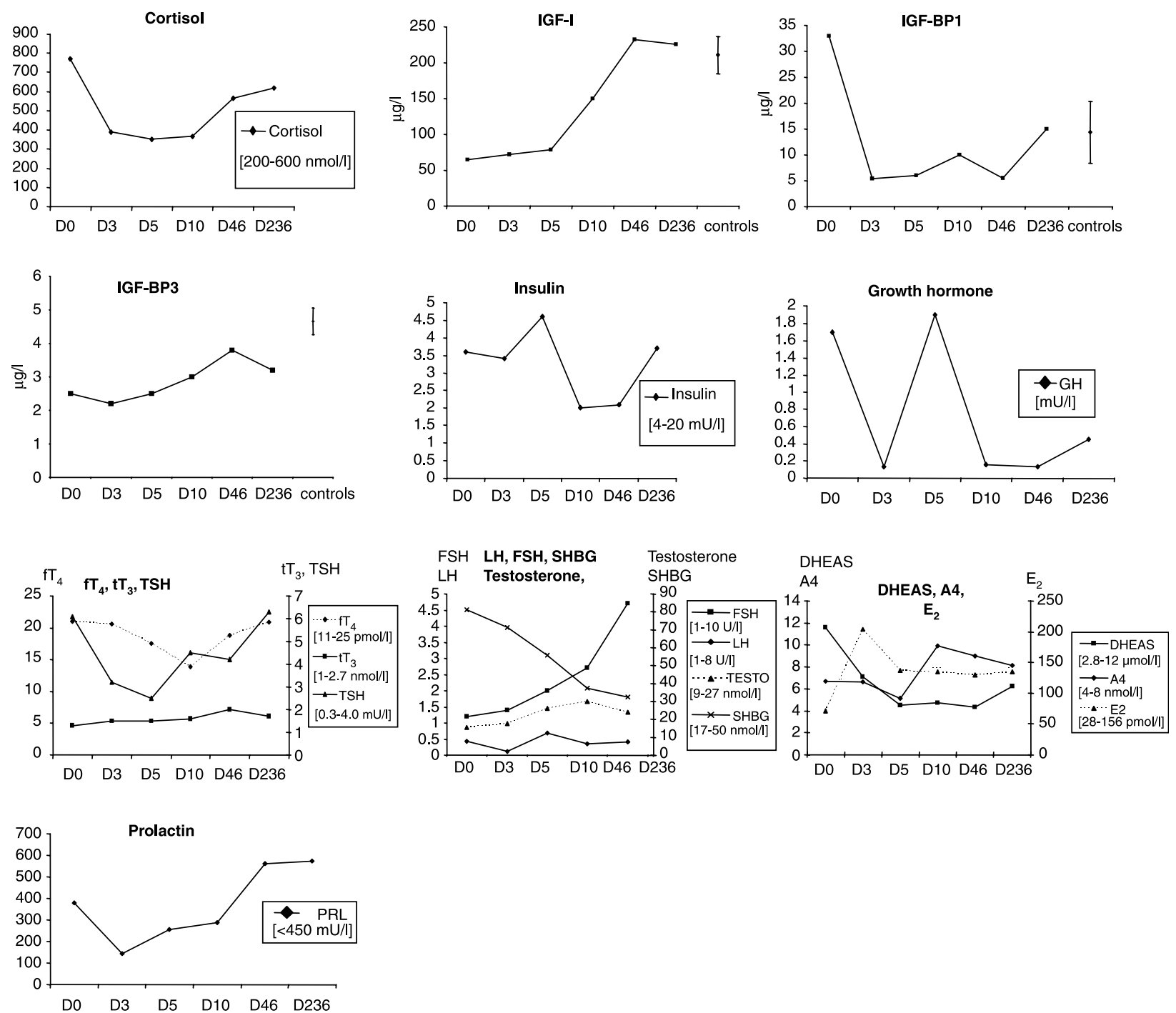

Figure 2 Classical hormone levels during refeeding are shown with either normal range in square brackets or as mean $\pm 95 \%$ confidence interval of hormone concentrations of healthy volunteers. $\mathrm{fT}_{4}$, free thyroxin; $\mathrm{tT}_{3}$, total tri-iodothyronine; $\mathrm{TSH}$, thyroid-stimulating hormone; $\mathrm{LH}_{\text {, luteinizing }}$ hormone; FSH, follicle-stimulating hormone; testosterone; $\mathrm{E}_{2}$, oestradiol; SHBG, sex hormone-binding globulin; DHEAS, dehydroepiandrosterone sulphate; A4, androstenedione; IGF-I, insulin-like growth factor I; IGF-BP1, insulin-like growth factor-binding protein 1. 

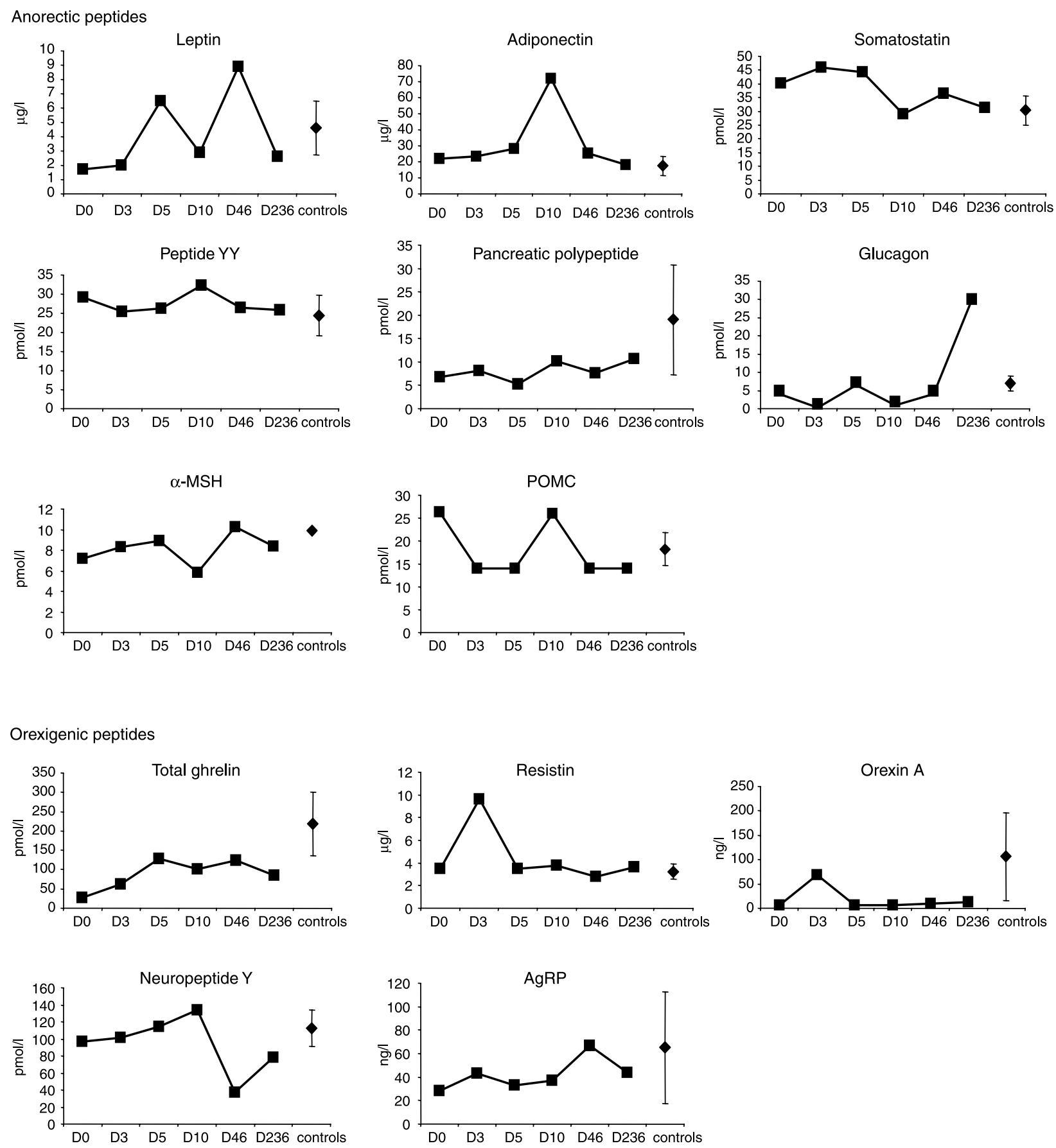

Figure 3 Anorectic and orexigenic peptides are shown during refeeding. Data for volunteers are shown as mean $\pm 95 \%$ confidence interval. AgRP, agouti-related peptide; POMC, proopiomelanocortin; $\alpha$-MSH, $\alpha$-melanocyte-stimulating hormone.

body composition and the appetite- and central feedingrelated peptides.

\section{Discussion}

The study subject showed evidence of haemoconcentration as judged by the haematocrit. As refeeding raises plasma insulin, potassium, phosphate and magnesium are driven intracellularly, and sodium extracellularly, expanding circulating volume and causing haemodilution, as indicated in D B by changes in his haematocrit and albumin levels. The plasma expansion during the early refeeding period, which can precipitate heart failure, emphasizes the clinical need for sodium restriction and the potential dangers 
Table 4 Glucose, free fatty acid and hormonal parameters.

\begin{tabular}{|c|c|c|c|c|c|c|c|c|c|}
\hline Hormone & Unit & Day 0 & Day 3 & Day 5 & Day 10 & Day 46 & Day 236 & $\begin{array}{c}\text { Mean of } \\
\text { controls } \\
\text { or normal } \\
\text { range }\end{array}$ & $\begin{array}{l}\text { Range of } \\
\text { controls }\end{array}$ \\
\hline Fasting glucose & $\mathrm{mmol} / \mathrm{l}$ & 5.20 & 5.10 & 5.30 & 4.70 & 4.50 & 4.70 & 4.50 & $3.8-5.3$ \\
\hline Free fatty acid & $\mathrm{mmol} / \mathrm{l}$ & 1.53 & 1.25 & 0.27 & 0.21 & 0.18 & 0.60 & 0.50 & $0.1-0.98$ \\
\hline 3-hydroxybutyrate & $\mathrm{mmol} / \mathrm{l}$ & 4.92 & 0.81 & 0.02 & 0.02 & 0.02 & 0.09 & 0.16 & $0.02-1.38$ \\
\hline $\begin{array}{l}\text { ETKAC (related to } \\
\text { vitamin B1) }\end{array}$ & & 2.68 & 1.22 & 1.17 & 1.13 & 1.24 & 1.16 & 1.15 & $1.06-1.22$ \\
\hline $\begin{array}{l}\text { EGRAC (related to } \\
\text { vitamin B2) }\end{array}$ & & 1.51 & 1.04 & 1.10 & 1.07 & 1.40 & 1.70 & 1.25 & $1.10-1.36$ \\
\hline $\begin{array}{l}\text { EAATAC (related to } \\
\text { vitamin B6) }\end{array}$ & & 4.05 & 3.47 & 2.84 & 2.06 & 1.61 & 1.64 & 2.05 & $1.78-2.49$ \\
\hline B12 & $\mathrm{ng} / \mathrm{l}$ & 1500 & 1326 & 1146 & 798 & 676 & 555 & 323 & $194-419$ \\
\hline Serum folate & $\mu \mathrm{g} / \mathrm{l}$ & 3.09 & 20 & 20 & 5.08 & 6.02 & 6.92 & 6.29 & $4.0-11.5$ \\
\hline Homocysteine & $\mu \mathrm{mol} / /$ & 8.65 & 10.61 & 7.75 & 6.02 & 6.21 & 7.94 & 9.66 & $6.1-13.5$ \\
\hline Cortisol & $\mathrm{nmol} / \mathrm{l}$ & 770.00 & 390.00 & 349.00 & 368.00 & 564.00 & 618.00 & $200-600$ & \\
\hline IGF-I & $\mu \mathrm{g} / \mathrm{l}$ & 65.00 & 72.00 & 79.00 & 150.00 & 232.00 & 226.00 & 210.88 & $125-295$ \\
\hline IGF-BP1 & $\mu \mathrm{g} / \mathrm{l}$ & 33.00 & 5.40 & 6.00 & 10.00 & 5.50 & 15.00 & 14.36 & $2.7-38$ \\
\hline IGF-BP3 & $\mathrm{mg} / \mathrm{l}$ & 2.50 & 2.20 & 2.50 & 3.00 & 3.80 & 3.20 & 4.64 & $3.0-5.8$ \\
\hline Insulin & $\mathrm{mU} / \mathrm{l}$ & 3.60 & 3.40 & 4.60 & 2.00 & 2.10 & 3.70 & $4.0-20$ & \\
\hline Growth hormone & $\mathrm{mU} / \mathrm{l}$ & 1.70 & 0.13 & 1.90 & 0.16 & 0.13 & 0.45 & Variable & \\
\hline $\mathrm{fT}_{4}$ & $\mathrm{pmol} / \mathrm{l}$ & 21.00 & 20.60 & 17.50 & 13.90 & 18.80 & 20.90 & $11-25$ & \\
\hline $\mathrm{tT}_{3}$ & $\mathrm{nmol} / \mathrm{l}$ & 1.30 & 1.50 & 1.50 & 1.60 & 2.00 & 1.70 & $1-2.7$ & \\
\hline TSH & $\mathrm{mU} / \mathrm{l}$ & 6.10 & 3.20 & 2.50 & 4.50 & 4.20 & 6.30 & $0.3-4.01$ & \\
\hline $\mathrm{LH}$ & $\mathrm{U} / \mathrm{I}$ & 7.80 & 2.10 & 12.30 & 6.40 & 7.40 & NA & $1-8$ & \\
\hline FSH & $\mathrm{U} / \mathrm{I}$ & 1.20 & 1.40 & 2.00 & 2.70 & 4.70 & NA & $1-10$ & \\
\hline SHBG & $\mathrm{nmol} / \mathrm{l}$ & 81.30 & 71.30 & 55.80 & 37.30 & 32.50 & NA & $17-50$ & \\
\hline TESTO & $\mathrm{nmol} / \mathrm{l}$ & 15.60 & 17.60 & 26.20 & 30.10 & 23.90 & NA & $9-27$ & \\
\hline DHEAS & $\mu \mathrm{mol} / /$ & 11.60 & 7.10 & 4.50 & 4.70 & 4.30 & 6.20 & $2.8-12$ & \\
\hline Androstenedione & $\mathrm{nmol} / \mathrm{l}$ & 6.70 & 6.60 & 5.10 & 9.90 & 9.00 & 8.10 & $4-8$ & \\
\hline Oestradiol & $\mathrm{pmol} / \mathrm{l}$ & 70.80 & 204.00 & 137.00 & 135.00 & 130.00 & 135.00 & $28-156$ & \\
\hline PRL & $\mathrm{mU} / \mathrm{l}$ & 378.00 & 143.00 & 256.00 & 289.00 & 563.00 & 573.00 & $<450$ & \\
\hline Gastrin & $\mathrm{pmol} / \mathrm{l}$ & 0.77 & 1.51 & 0.91 & 0.73 & 0.77 & 3.20 & 2.60 & $0.5-9.6$ \\
\hline Leptin & $\mathrm{ng} / \mathrm{ml}$ & 1.70 & 2.00 & 6.50 & 2.90 & 8.90 & 2.60 & 4.62 & $1.7-14.7$ \\
\hline Adiponectin & $\mathrm{ng} / \mathrm{ml}$ & 22.10 & 23.50 & 27.90 & 71.90 & 25.10 & 17.90 & 17.40 & $3.4-38.6$ \\
\hline Somatostatin & $\mathrm{pmol} / \mathrm{l}$ & 40.33 & 45.87 & 44.25 & 29.15 & 36.48 & 31.26 & 30.39 & $16.6-49.2$ \\
\hline PYY & $\mathrm{pmol} / \mathrm{l}$ & 29.27 & 25.36 & 26.15 & 32.31 & 26.38 & 25.92 & 24.47 & $10.5-50.1$ \\
\hline PP & $\mathrm{pmol} / \mathrm{l}$ & 6.69 & 8.18 & 5.26 & 10.15 & 7.61 & 10.73 & 19.06 & $7.0-84.6$ \\
\hline Glucagon & $\mathrm{pmol} / \mathrm{l}$ & 4.83 & 1.28 & 7.29 & 1.94 & 4.88 & 30.03 & 7.03 & $0.4-14.1$ \\
\hline$\alpha-M S H$ & $\mathrm{pmol} / \mathrm{l}$ & 7.20 & 8.30 & 8.90 & 5.80 & 10.30 & 8.40 & 9.88 & $3.8-18.6$ \\
\hline POMC & $\mathrm{pmol} / \mathrm{l}$ & 26.40 & 14.00 & 14.00 & 26.00 & 14.00 & 14.00 & 18.23 & $14-36.3$ \\
\hline Total ghrelin & $\mathrm{pmol} / \mathrm{l}$ & 27.60 & 61.90 & 127.40 & 100.10 & 123.70 & 84.80 & 218.07 & $28-687$ \\
\hline Orexin A & $\mathrm{ng} / \mathrm{l}$ & 7.00 & 69.00 & 7.00 & 6.00 & 9.00 & 13.00 & 106.25 & $0.5-55$ \\
\hline Resistin & $\mathrm{ng} / \mathrm{ml}$ & 3.50 & 9.60 & 3.50 & 3.80 & 2.80 & 3.60 & 3.24 & $1.6-5.9$ \\
\hline NPY & $\mathrm{pmol} / \mathrm{l}$ & 96.40 & 101.20 & 114.30 & 134.20 & 37.50 & 78.50 & 112.32 & $26-170.1$ \\
\hline AgRP & $\mathrm{ng} / \mathrm{l}$ & 28.00 & 43.00 & 33.00 & 37.00 & 67.00 & 44.00 & 65.25 & $2.2-9.1$ \\
\hline
\end{tabular}

Vitamin B1, erythrocyte transketolase activation coefficient (ETKAC); vitamin B2, erythrocyte glutathione reductase activation coefficient (EGRAC); vitamin B6, erythrocyte aspartate aminotransferase activation coefficient (EAATAC): elevated results in these assays suggest vitamin deficiency.

of i.v. saline, though some still advocate this as a routine (13). Hypophosphataemia occurred despite a restricted oral energy intake, which was well below that required to meet the demands of the basal metabolic rate.

Elevated bilirubin concentrations and liver enzymes are a known complication of starving in humans (13-16) and our subject's results suggest that the observed changes seen may reflect a harmless, perhaps physiological effect of the refeeding process. Elevated levels of vitamin B12 and zinc are probably due to loss from liver and other lean tissues because of tissue catabolism during fasting, or could represent changes in
B12 kinetics, transport proteins or enterohepatic circulation $(17,18)$. Vitamins B1 and B6 were depleted over the period of the fast and were replenished early. Glucose by mouth or by vein without such replacement carries dangers of acute thiamine deficiency and lactic acidosis (19). There is a rapid metabolic shift from the fasting, fat-burning state to a carbohydrate-based 'mixed economy' based on the content of the feed ingested. Carbohydrate intake stimulates sodium and water retention, hypophosphataemia and other electrolyte shifts, and places demand on vitamin B1 requirements which can precipitate acute deficiency syndromes. 
On arrival in hospital, the patient was subject to the stress of the starvation itself; in addition, he experienced intense media attention, and both may have contributed to the high serum cortisol concentration despite the late evening hour $(2215 \mathrm{~h})$. It is possible that this high blood cortisol contributed to the relatively normal blood glucose concentration observed on arrival in hospital as well as to the high IGF-BP1 concentrations. IGF-BP1 is stimulated by cortisol especially in low insulin states (20). IGF-I is regulated by nutritional status independent of growth hormone, and is suppressed in nutritionally deprived subjects, even when elevated GH levels are present as, for example, in patients with anorexia nervosa (21). The mechanism causing low IGF-I and high IGF-BP1 in fasting could involve the cellular energy sensor enzyme AMP-activated protein kinase (AMPK; $22,23)$. This enzyme is activated during fasting and it inhibits the synthesis of IGF-I and upregulates IGF-BP1 $(24,25)$, and could explain the hormone changes in our subject. Prolonged fasting reduces TSH, probably via low leptin concentrations (21). However, we observed slightly elevated TSH which was probably the result of the acute psychological stress (26) at the time of blood sampling, although the exposure to cold, which was experienced in the last days of the fast in the box above the river Thames in October could have also played a part. Prolonged fasting causes hypothalamic hypogonadism and the low normal FSH, LH and testosterone and oestrogen concentrations, which increased during refeeding, suggest that this was the case in our subject. Low leptin concentrations have been suggested to play an important role in fasting-induced hypogonadism (27).

The patient though undoubtedly keen to eat again when he came out of the box after the fast was able to cope psychologically with the very cautious artificial refeeding programme to which he was restricted during the first 3 days. According to his diary, on day 1 he experienced abdominal cramps and "was not yet ready to eat but the thought of chewing and tasting again was so strong'. On day 2 , he continued to have cramps but started to crave food, while on day 3 'I could not help it; I wasn't hungry but just wanted to eat once again'. On day 5, 'my hunger grew out of proportion and I was eating almost a double portion of all meals'. The high 3-hydroxybutyrate concentration measured could contribute to low appetite on the first few days (28). The peripheral appetite hormone ghrelin levels are characteristically high after an overnight fast, but longer fasting (2-3 days) results in low ghrelin levels (29-31), and we now extend this observation of low ghrelin levels to 44 days. The discrepancy between low ghrelin concentrations with prolonged fasting and high ghrelin concentrations observed in patients with cachexia or anorexia nervosa could possibly be explained by circulating somatostatin concentrations. In patients with anorexia nervosa, somatostatin tone is low (32), while fasting for 2-4 days increases circulating somatostatin concentrations levels in healthy volunteers $(33,34)$. Here, we also observed high somatostatin concentrations which could be responsible for the low ghrelin concentrations. Subacute and long-term changes in nutrient intake regulate leptin levels in addition to changes in fat mass (35) and the low leptin concentrations we observed could have contributed to the modestly underactive gonadal axis. Apart from leptin and ghrelin, several other hormones are known to influence metabolism such as adiponectin and resistin, and to affect appetite, including the peripheral hormones PYY and PP (anorectic hormones) and adipokines adiponectin and resistin, as well as central hypothalamic hormones NPY, AGRP, orexin A (orexigenic) and $\alpha$-MSH (anorectic peptide). The complex interplay between these central and peripheral hormones probably regulates the altered metabolism of the fasting subjects, but the peripheral hormone levels which are available for measurement in a human study do not necessarily provide an exact explanation of the central and peripheral hormonal adaptation to fasting.

Our subject's feeling of hunger increased considerably by days $4-5$ and this was preceded by elevations in plasma orexin A and resistin on day 3. Previous data showed no change in resistin concentrations after 48-h fast in healthy subjects (36), while centrally administered resistin stimulates Fos expression in the rat arcuate nucleus during fasting and a role in appetite regulation has been suggested (37). Orexin A, a hormone primarily involved in arousal and secondarily with increases in appetite, shows elevated hypothalamic mRNA levels in animal studies during fasting (38), but little is known of the regulation of circulating orexin A concentrations in humans. AgRP was shown to rise with fasting, while no $\alpha$-MSH change was observed (39). Interestingly, plasma orexin A was lower when NPY was higher in obese women (40). PYY, a colon-derived hormone, inhibits appetite and the levels of PYY are lower in patients with simple obesity, raising the possibility that PYY deficiency may contribute to the pathogenesis of obesity $(3,41)$. Our finding that long-term fasting does not change PYY levels, corresponds to earlier data in normal and anorectic subjects $(42,43)$. During the refeeding period, we did not take blood samples after food intake; therefore, the PYY response could not be evaluated after a meal in our subject. While adipose tissue hormones resistin, adiponectin and leptin, and gastrointestinal hormones ghrelin and PYY have clear endocrine roles relaying information from the periphery to the hypothalamic appetite-regulating centres (44), the importance of circulating levels of specific hypothalamic orexigenic (NPY, orexin A and AgRP) and anorectic peptides (POMC and $\alpha-\mathrm{MSH})$ is still unclear.

In summary, this case presented an opportunity to study refeeding in detail and to measure metabolic and appetite-modulating hormones, which have only recently been described. We observed hypophosphataemia during refeeding, vitamin deficiencies, abnormal liver function, 
low IGF-I, leptin and low ghrelin levels, and a transient increase in plasma orexin and resistin levels at the time of increase in subjective feeling of hunger. We would like to note that our index subject's appearance after the fast reflecting a BMI of 21 would not have alerted us to the risks of refeeding had we not known about his history of no calorie intake and weight loss.

\section{Acknowledgements}

We are indebted to Professor Ashley B Grossman (Barts and the London Medical School) for reviewing the manuscript and to the colleagues who helped to collect and analyze the blood samples: John Eldridge, Tony Taylor, Tom Thomson, Vic Clarke, Helga Griffiths (London Independent Hospital), Kate Noonan, Clare Soulsby, Alison Chambers, Lisa Chapman, Gillian Perry, Cecilia Camacho-Hübner (Barts and the London Medical School), Valerie Walker, John Jackson (Southampton University), Professor Mohamed Ghatei, Michael Patterson (Imperial College), Adam Cunliffe, Rumy Begum, Carol Cray (University of Westminster), Sharon Ajodha (NETRIA, London) and Steve Krywawych (Great Ormond Street Hospital).

\section{References}

1 Collins S. The limit of human adaptation to starvation. Nature Medicine 19951 810-814.

2 Korbonits M, Blaine D, Elia M \& Powell-Tuck J. Refeeding Blaine: studies following a 44 day fast. New England Journal of Medicine $20053532306-2307$.

3 Batterham RL, Cowley MA, Small CJ, Herzog H, Cohen MA, Dakin CL, Wren AM, Brynes AE, Low MJ, Ghatei MA, Cone RD \& Bloom SR. Gut hormone PYY(3-36) physiologically inhibits food intake. Nature $2002 \mathbf{4 1 8} 650-654$.

4 Durnin JV \& Womersley J. Body fat assessed from total body density and its estimation from skinfold thickness: measurements on 481 men and women aged from 16 to 72 years. British Journal of Nutrition 197432 77-97.

5 Jackson JM, Blaine D, Powell-Tuck J. Korbonits M, Carey A \& Elia M. Macro- and micronutrient losses and nutritional status resulting from 44 days of total fasting in a non-obese man. Nutrition 200622 889-897.

6 Terlevich A, Hearing SD, Woltersdorf WW, Smyth C, Reid D, McCullagh E, Day A \& Probert CS. Refeeding syndrome: effective and safe treatment with Phosphates Polyfusor. Alimentary Pharmacology and Therapeutics $2003 \mathbf{1 7} 1325-1329$.

7 Glynn MJ, Powell-Tuck J, Reavely DA \& Murray-Lyon IM. High lipid parenteral feeds raise plasma branched chain amino acid concentrations - a possible therapeutic approach to portasystemic encephalopathy? Clinical Nutrition 19865 109-112.

8 Keys A, Brozek J, Henschel A, Mickelsen O \& Taylor HL. The Biology of Human Starvation. Minneapolis: University of Minnesota press, 1950.

9 Schnitker MA, Mattman PE \& Bliss TL. A clinical study of malnutrition in Japanese prisoners of war. Annals of Internal Medicine 195135 69-96.

10 Gozansky DM \& Herman RH. Water and sodium retention in the fasted and refed human. American Journal of Clinical Nutrition 1971 24 869-871.
11 Silvis SE \& Paragas PD, Jr. Paresthesias, weakness, seizures, and hypophosphatemia in patients receiving hyperalimentation. Gastroenterology 197262 513-520.

12 Travis SF, Sugerman HJ, Ruberg RL, Dudrick SJ, DelivoriaPapadopoulos M, Miller LD \& Oski FA. Alterations of red-cell glycolytic intermediates and oxygen transport as a consequence of hypophosphatemia in patients receiving intravenous hyperalimentation. New England Journal of Medicine 1971285 763-768.

13 Faintuch J, Soriano FG, Ladeira JP, Janiszewski M, Velasco IT \& Gama-Rodrigues JJ. Refeeding procedures after 43 days of total fasting. Nutrition 200117 100-104.

14 Abraira C, Virupannavar C \& Nemchausky B. Protective effect of small amounts of glucose on abnormal liver function tests during starvation. Metabolism: Clinical and Experimental 198029 943-948.

15 Oster P, Mordasini R, Raetzer H, Schellenberg B \& Schlierf G. Complications in null-diet. Schweizerische Medizinische Wochenschrift 1977107 1313-1317.

16 Solomon SM \& Kirby DF. The refeeding syndrome: a review. Journal of Parenteral and Enteral Nutrition 199014 90-97.

17 Himmerich H, Anghelescu I, Klawe C \& Szegedi A. Vitamin B12 and hepatic enzyme serum levels correlate in male alcoholdependent patients. Alcohol and Alcoholism 200136 26-28.

18 Gibney ER, Faber AR, Johnstone AM, Stubbs RJ \& Elia M. Effect of 5 day total starvation in healthy men uncomplicated by disease on circulating levels of plasma folate, B12 and bilirubin. Proceedings of the Nutrition Society 200059 164A (Abstract).

19 From the Centers for Disease Control and Prevention. Lactic acidosis traced to thiamine deficiency related to nationwide shortage of multivitamins for total parenteral nutrition-United States, 1997. JAMA 1997278 109-111.

20 Conover CA, Divertie GD \& Lee PD. Cortisol increases plasma insulin-like growth factor binding protein-1 in humans. Acta Endocrinologica 1993128 140-143.

21 Stoving RK, Hangaard J, Hansen-Nord M \& Hagen C. A review of endocrine changes in anorexia nervosa. Journal of Psychiatric Research 199933 139-152.

22 Kahn BB, Aliquier T, Carling D \& Hardie DG. AMP-activated protein kinase: ancient energy gauge provides clues to modern understanding of metabolism. Cell Metabolism 20051 15-25.

23 Kola B, Hubina E, Tucci SA, Kirkham TC, Garcia EA, Mitchell SE, Williams LM, Hawley SA, Hardie DG, Grossman AB \& Korbonits M. Cannabinoids and ghrelin have both central and peripheral metabolic and cardiac effects via AMP-activated protein kinase. Journal of Biological Chemistry $200528025196-25201$.

24 McCarty MF. Chronic activation of AMP-activated kinase as a strategy for slowing aging. Medical Hypotheses 200463 334-339.

25 Luo Z, Saha AK, Xiang X \& Ruderman NB. AMPK, the metabolic syndrome and cancer. Trends in Pharmacological Sciences 200526 69-76.

26 Richter SD, Schurmeyer TH, Schedlowski M, Hadicke A, Tewes U, Schmidt RE \& Wagner TO. Time kinetics of the endocrine response to acute psychological stress. Journal of Clinical Endocrinology and Metabolism 199681 1956-1960.

27 Ahima RS, Prabakran D, Mantzoros C, Qu D, Lowell B, MaratosFlier E \& Flier JS. Role of leptin in the neuroendocrine response to fasting. Nature 1996382 250-252.

28 Arase K, Fisler IS, Shargill NS, York DA \& Bray GA. Intracerebroventricular infusions of 3-OHB and insulin in a rat model of dietary obesity. American Journal of Physiology $1988 \mathbf{2 5 5}$ R974-R981.

29 Hansen TK, Dall R, Hosoda H, Kojima M, Kangawa K, Christiansen JS \& Jorgensen JO. Weight loss increases circulating levels of ghrelin in human obesity. Clinical Endocrinology $2002 \mathbf{5 6}$ 203-206.

30 Muller AF, Lamberts SW, Janssen JA, Hofland LJ, Koetsveld PV, Bidlingmaier M, Strasburger CJ, Ghigo E \& van der Lely AJ. Ghrelin drives GH secretion during fasting in man. European Journal of Endocrinology $2002146203-207$.

31 Espelund U, Hansen TK, Hojlund K, Beck-Nielsen H, Clausen JT, Hansen BS, Orskov H, Jorgensen JO \& Frystyk J. Fasting unmasks a 
strong inverse association between ghrelin and cortisol in serum: studies in obese and normal-weight subjects. Journal of Clinical Endocrinology and Metabolism 200590 741-746.

32 Stoving RK, Andersen M, Flyvbjerg A, Frystyk J, Hangaard J, Vinten J, Koldkjaer OG \& Hagen C. Indirect evidence for decreased hypothalamic somatostatinergic tone in anorexia nervosa. Clinical Endocrinology 200256 391-396.

33 Thuesen B, Schaffalitzky de Muckadell OB, Holst JJ \& Bahnsen M. The relationship of secretin and somatostatin levels in plasma to glucose administration and acid secretion during fasting. American Journal of Gastroenterology 198782 723-726.

34 Coiro V, Volpi R, Capretti L, Caffarri G, Colla R \& Chiodera P. Effects of pyridostigmine and naloxone on the abnormal TSH response to TRH during starvation in humans. Journal of Investigative Medicine $199947227-231$.

35 Kolaczynski JW, Considine EL, Ohannesian J, Marco C, Opentanova I, Nyce MR, Myint M \& Caro JF. Responses of leptin to short-term fasting and refeeding in humans - a link with ketogenesis but not ketones themselves. Diabetes $1996 \mathbf{4 5}$ 1511-1515.

36 Lee JH, Chan JL, Yiannakouris N, Kontogianni M, Estrada E, Seip R, Orlova C \& Mantzoros CS. Circulating resistin levels are not associated with obesity or insulin resistance in humans and are not regulated by fasting or leptin administration: cross-sectional and interventional studies in normal, insulin-resistant, and diabetic subjects. Journal of Clinical Endocrinology and Metabolism $2003 \mathbf{8 8} 4848-4856$.

37 Tovar S, Nogueiras R, Tung LY, Castaneda TR, Vazquez MJ, Morris A, Williams LM, Dickson SL \& Dieguez C. Central administration of resistin promotes short-term satiety in rats. European Journal of Endocrinology 2005153 R1-R5.

38 Sutcliffe JG \& de Lecea L. The hypocretins: excitatory neuromodulatory peptides for multiple homeostatic systems, including sleep and feeding. Journal of Neuroscience Research 200062 161-168.
39 Gavrila A, Chan JL, Miller LC, Heist K, Yiannakouris N \& Mantzoros CS. Circulating melanin-concentrating hormone, agouti-related protein, and alpha-melanocyte-stimulating hormone levels in relation to body composition: alterations in response to food deprivation and recombinant human leptin administration. Journal of Clinical Endocrinology and Metabolism 200590 1047-1054.

40 Baranowska B, Wolinska-Witort E, Martynska M, Chmielowska M \& Baranowska-Bik A. Plasma orexin A, orexin B, leptin, neuropeptide Y (NPY) and insulin in obese women. Neuro Endocrinology Letters 200526 293-296.

41 Batterham RL, Cohen MA, Ellis SM, Le Roux CW, Withers DJ, Frost GS, Ghatei MA \& Bloom SR. Inhibition of food intake in obese subjects by peptide YY3-36. New England Journal of Medicine 2003 349 941-948.

42 Stock S, Leichner P, Wong AC, Ghatei MA, Kieffer TJ, Bloom SR \& Chanoine JP. Ghrelin, peptide YY, glucose-dependent insulinotropic polypeptide, and hunger responses to a mixed meal in anorexic, obese, and control female adolescents. Journal of Clinical Endocrinology and Metabolism 200590 2161-2168.

43 Garcia JM, Garcia-Touza M, Hijazi RA, Taffet G, Epner D, Mann D, Smith RG, Cunningham GR \& Marcelli M. Active ghrelin levels and active to total ghrelin ratio in cancer-induced cachexia. Journal of Clinical Endocrinology and Metabolism $2005902920-2926$.

44 Blevins JE, Schwartz MW \& Baskin DG. Peptide signals regulating food intake and energy homeostasis. Canadian Journal of Physiology and Pharmacology $2002 \mathbf{8 0} 396-406$.

Received 13 December 2006

Accepted 10 May 2007 